\title{
Study of the Effect Clay Substitution with Wood Sawdust and Hydroton on Compressive Strength, Density and Water Absorption of Red Brick Case Study of Traditional Red Brick Industry in Singgahan Village
}

\author{
Raka Candra Fitrian*, Agung Sumarno \\ Department of Civil Engineering, Faculty of Engineering, Mercu Buana University, West Java, Indonesia \\ *Corresponding author E-mail: rakacandrafitrian@gmail.com
}

\begin{abstract}
Manuscript received 1 Jan 2021; revised 10 Jan 2021; accepted 15 Jan 2021. Date of publication 20 Jan 2021
Abstract

Redbrick is one of the building materials which is commonly used as a basic building material. In the traditional red brick factory in the village of Singgahan Tuban, East Java, some problems are often encountered in the field, namely red bricks that are cracked and broken on the bricks at the bottom of the pile. This has an impact on results that are not on target. The purpose of this study was to determine the effect of wood sawdust and hydroton substitution on the compressive strength, density, and water absorption capacity of redbrick. Using an experimental method with a substitution ratio of wood sawdust and hydroton of 5\%, 10\%, and 15\%. Manufacture of 50 red bricks measuring $23 \times 11 \times 4.5 \mathrm{~cm}$. The drying process is carried out for 5 days then burned at $900^{\circ} \mathrm{C}$ for 2 days. From the test, it was found that the red brick without substitution had a compressive strength value of $8.95 \mathrm{MPa}$, a density value of 1.59 grams / $\mathrm{cm}^{3}$, and a water absorption capacity of $11.14 \%$. The red brick substitution of wood sawdust waste has a compressive strength value of $6.25 \mathrm{MPa}$, a density value of 1.48 grams $/ \mathrm{cm}^{3}$ and a water absorption capacity of $12.04 \%$. In the red brick, the hydroton substitution has a compressive strength value of $9.27 \mathrm{MPa}$, a density value of 1.64 grams/cm air, and a water absorption capacity of $11.22 \%$.
\end{abstract}

Keywords: Redbrick, Traditional Redbrick, Compressive Strength, Density, Water Absorption.

\section{Introduction}

Redbrick is often chosen as a construction material because it is easy to work with, the price is quite cheap, does not require special adhesives, and high resistance to fire. Redbrick application for construction materials, in the form of walls in residential buildings and buildings, as well as fences and foundations. In general, in building construction, red brick functions as both a structural and nonstructural material. The disadvantage of red brick, when compared to other brick products on the market, is a higher mass but a smaller volume so that mortar tends to be wasteful when used as a wall mount. Previous research related to improving the quality of red brick was to increase the value of compressive strength by utilizing several additional materials such as sawdust waste, bagasse waste, river sand, and also coconut fiber.

Faisal Khoufi and Purnomo Budi Santoso researched the effect of sawdust ash mixture on the compressive strength of red brick. The results of the test for the compressive strength of bricks with a mixture of sawdust ashes, a ratio of $2.5 \%$ of 2.7 Mpa is greater than that of without mixture or pure clay, which is $2.09 \mathrm{Mpa}$. Rudi Hartono and Elhusna conducted a study to determine the effect of adding rice husk ash on the mechanical properties of red brick. The result of the compressive strength test of red bricks with a mixture of rice husk ash with a ratio of $5 \%$ was $2.56 \mathrm{MPa}$ lower than the red bricks without a mixture of $3.16 \mathrm{MPa}$. From previous research, it can be concluded that the difference in the mixed material in the manufacture of red brick affects the compressive strength test results. In this study, the researcher wanted to study the effect of the sawdust mixture on the compressive strength of red brick and add other mixed materials that had not been used in previous studies, namely material hydroton. The target of the test object to be made has a compressive strength close to class 50 or $5 \mathrm{Mpa}$. 


\section{Methods}

This research using an experimental method carried out by experimenting to obtain data that connects the variables studied. The independent variable in this study is the substitution of wood sawdust and hydroton against clay which is assumed to affect the compressive strength, density, and water absorption capacity of red brick. Of the total number of 50 specimens, 40 bricks were used for the compressive strength test which was cut into $5 \mathrm{~cm} \mathrm{x} 5 \mathrm{~cm}$ sizes, and 10 bricks were intact for the measurement of water absorption. There are ten types of specimens that are differentiated based on the ratio of the sub concentration of clay to sawdust and hydroton which are detailed in the following table :

Table 1. Mix design of test object

\begin{tabular}{c|c|c|c|c}
\hline \multirow{2}{*}{ No. } & \multirow{2}{*}{ Sample } & \multicolumn{3}{|c}{ Weight (grams) } \\
\cline { 3 - 5 } & & Clay & Sawdust & Hydroton \\
\hline 1 & A & 2250 & 0 & 0 \\
\hline 2 & B1 & 2137,5 & 112,5 & 0 \\
\hline 3 & B2 & 2025 & 225 & 0 \\
\hline 4 & B3 & 1912,5 & 337,5 & 0 \\
\hline 5 & C1 & 2137,5 & 0 & 112,5 \\
\hline 6 & C2 & 2025 & 0 & 225 \\
\hline 7 & C3 & 1912,5 & 0 & 337,5 \\
\hline 8 & D1 & 2137,5 & 56,25 & 56,25 \\
\hline 9 & D2 & 2025 & 112,5 & 112,5 \\
\hline 10 & D3 & 1912,5 & 168,75 & 168,75 \\
\hline
\end{tabular}

The main activities carried out in this study include making test objects carried out in a conventional brick factory in the village of Singgahan Tuban, East Java. Examination properties visible, compressive strength testing, density measurement, and water absorption testing refers to SNI 15-2094-2000 regarding solid red brick masonry. Testing was carried out at the laboratory of Batching Plant PT. Waskita Beton Precast, Cileungsi Bogor West Java. Then analyze the test data that has been obtained.

\section{Results and Discussion}

\subsection{Result of compressive strength test}

The process of calculating the compressive strength of the test object requires two parameters, namely the area of the compressive plane and the compressive load. The tool used is a digital compression machine Teguh primatama with a capacity of $2000 \mathrm{kN}$. Following the table results of the compressive strength test :

Table 2. The results of the compressive strength test

\begin{tabular}{c|c|c|c|c}
\hline \multirow{2}{*}{ No } & \multirow{2}{*}{ Sample } & $\begin{array}{c}\text { Size } \\
\left(\mathbf{c m}^{2}\right)\end{array}$ & Load & $\begin{array}{c}\text { Compressing } \\
\text { Strength }\end{array}$ \\
\cline { 4 - 5 } & & & $(\mathbf{k N})$ & $\mathbf{( M P a )}$ \\
\hline 1 & A & 23,14 & 20,7 & 8,95 \\
\hline 2 & B1 & 23,67 & 14,8 & 6,25 \\
\hline 3 & B2 & 22,97 & 6,03 & 2,64 \\
\hline 4 & B3 & 23,68 & 4,8 & 2,02 \\
\hline 5 & C1 & 23,65 & 21,9 & 9,27 \\
\hline 6 & C2 & 23,4 & 11,8 & 5,06 \\
\hline 7 & C3 & 24,24 & 8,19 & 3,4 \\
\hline 8 & D1 & 23,98 & 103,3 & 4,44 \\
\hline 9 & D2 & 23,54 & 8,06 & 3,45 \\
\hline 10 & D3 & 24,04 & 5,81 & 2,42 \\
\hline
\end{tabular}

Results of testing the compressive strength of red brick with wood sawdust and waste substitution hydroton showed different results for each variation of the test object and its substitution ratio. Of the ten variations of the test object that succeeded in reaching the target were variation A (red brick without substitution), variation B1 (red brick substituted for sawdust with a ratio of 5\%), variation C1 (red brick substitution for hydroton with 5\% ratio), and variation C2 (brick red hydroton substitution ratio of 10\%). Meanwhile, the variations of B2, B3, C3, D1, D2, and D3 did not reach the target because the compressive strength value was below $5 \mathrm{Mpa}$. 


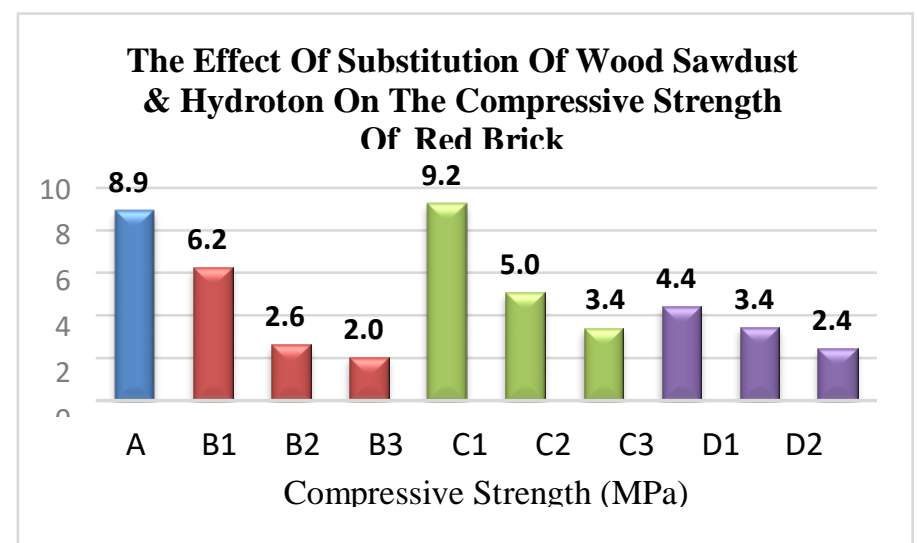

Fig 1. Chart of The Compressive Strength Test

\subsection{Result of water absorption test}

This test aims to determine the ability of bricks to absorb water in each variation of the specimen by immersing it in water for 24 hours. The value of water absorption is obtained from measurements of dry mass after the combustion process and mass after immersion, each of which is measured using a weighing device.

Table 3. The Result of the Water Sbsorption Test

\begin{tabular}{c|c|c|c|c|c|c}
\multicolumn{2}{c}{} & \multicolumn{5}{c}{ Table 3. The Result of the Water Sbsorption Test } \\
\cline { 3 - 6 } No & \multirow{2}{*}{ Sample } & $\begin{array}{c}\text { Before } \\
\text { Burning }\end{array}$ & $\begin{array}{c}\text { After } \\
\text { Burning }\end{array}$ & $\begin{array}{c}\text { After Im- } \\
\text { mersion 24 } \\
\text { Hours }\end{array}$ & $\begin{array}{c}\text { Water Ab- } \\
\text { Water } \\
\text { sorption (\%) }\end{array}$ & \\
\hline 1 & A & 1755 & 1480 & 1644,9 & 781,2 & 11,14 \\
\hline 2 & B1 & 1680 & 1394 & 1561,9 & 693,1 & 12,04 \\
\hline 3 & B2 & 1360 & 1055 & 1303,8 & 474,9 & 23,58 \\
\hline 4 & B3 & 1270 & 998 & 1300,4 & 427,2 & 30,30 \\
\hline 5 & C1 & 1645 & 1505 & 1673,8 & 775,4 & 11,22 \\
\hline 6 & C2 & 1564 & 1424 & 1647,2 & 675,6 & 15,67 \\
\hline 7 & C3 & 1487 & 1377 & 1634,5 & 600,4 & 18,70 \\
\hline 8 & D1 & 1630 & 1383 & 1559,8 & 677,7 & 12,78 \\
\hline 9 & D2 & 1557 & 1308 & 1530,6 & 619,1 & 17,02 \\
\hline 10 & D3 & 1415 & 1165 & 1387,2 & 468,1 & 19,07 \\
\hline
\end{tabular}

Based on SNI 15-2094-2000, the maximum water absorption limit for solid red brick for wall pairs is $20 \%$. This for the variation of B2 and B3 specimens, it is not suitable for use because the water absorption value exceeds $20 \%$. While the eight variations of the other specimens have a water absorption value of less than $20 \%$, this indicates that the red brick is suitable for use.

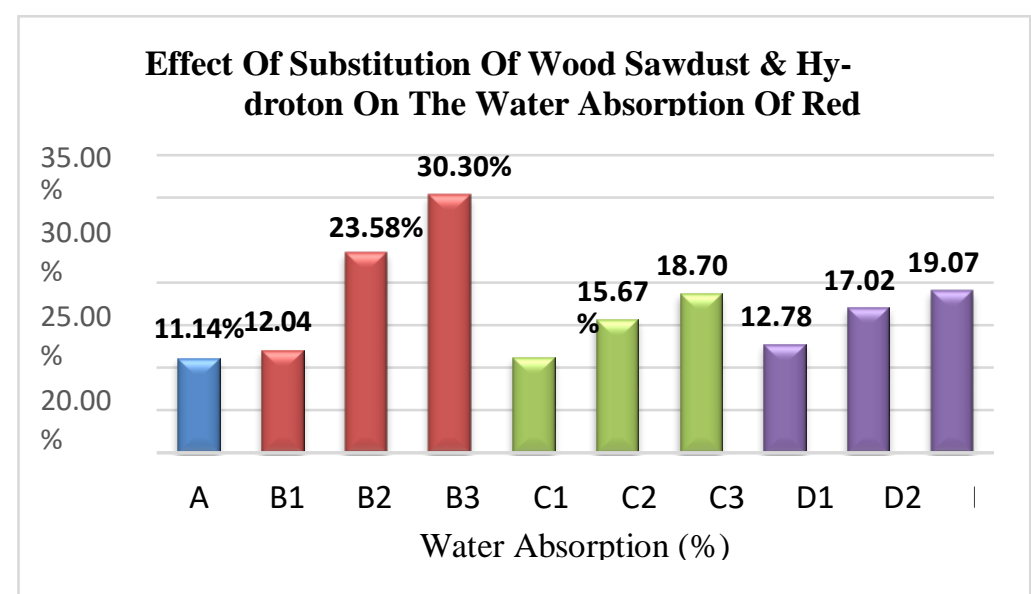

Fig 2. Chart of The Water Absorption Test 


\subsection{Result of density measurement}

Density is the mass of the sample contained in one volume unit. To obtain the density value of the test object required parameters, namely the dry mass after burning and the volume of red brick.

Table 4. Results of Density Measurement

\begin{tabular}{c|c|c|c|c|c|c|c}
\hline \multirow{2}{*}{ No } & \multirow{2}{*}{ Sample } & $\begin{array}{c}\text { Weight } \\
\text { (gr) }\end{array}$ & \multicolumn{2}{|c|}{ Dimensions (cm) } & \multirow{2}{*}{ Volume (cm) } & \multirow{2}{*}{ Density (gr/cm) } \\
\cline { 3 - 6 } & & $\begin{array}{c}\text { After } \\
\text { Burning }\end{array}$ & Lenght & Width & $\begin{array}{c}\text { Heigh } \\
\mathbf{t}\end{array}$ & & \\
\hline 1 & A & 1480 & 22,00 & 10,10 & 4,20 & 933,24 & 1,59 \\
\hline 2 & B1 & 1394 & 22,50 & 10,20 & 4,10 & 941,0 & 1,48 \\
\hline 3 & B2 & 1055 & 22,50 & 10,00 & 4,20 & 945 & 1,12 \\
\hline 4 & B3 & 998 & 23,00 & 10,30 & 4,10 & 971,3 & 1,03 \\
\hline 5 & C1 & 1505 & 22,50 & 10,20 & 4,00 & 918 & 1,64 \\
\hline 6 & C2 & 1424 & 23,30 & 10,20 & 4,10 & 974,4 & 1,46 \\
\hline 7 & C3 & 1377 & 23,00 & 10,30 & 4,00 & 947,6 & 1,45 \\
\hline 8 & D1 & 1383 & 22,50 & 10,00 & 4,00 & 900 & 1,54 \\
\hline 9 & D2 & 1308 & 22,50 & 10,30 & 4,30 & 996,5 & 1,31 \\
\hline 10 & D3 & 1165 & 23,00 & 10,30 & 4,00 & 947,6 & 1,23 \\
\hline
\end{tabular}

It is known that the higher the density of the red brick the greater the compressive strength value. And conversely, the smaller the density of the red brick, the greater the water absorption. This means that the smaller the density of the red brick, the less compact the bonds between the particles so that there is an air cavity in it. This causes water to be easily absorbed into these cavities.

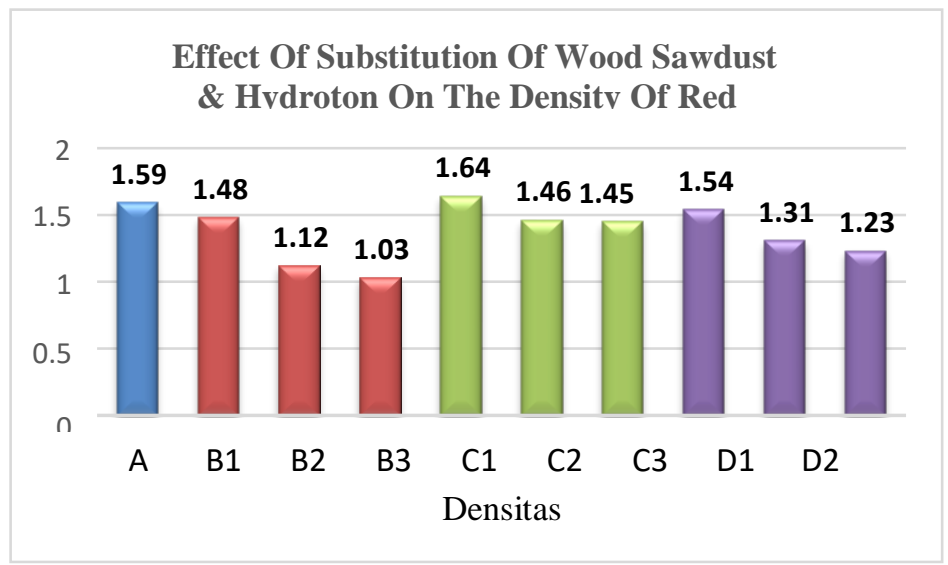

Fig 3. Chart of Density Measurement

\section{Conclusions}

Based on the research objectives and test results has been carried out on the red brick specimen with the substitution of sawdust and hydroton, the following conclusions are obtained :

a. The compressive strength value of red brick without substitution is $8.95 \mathrm{MPa}$. The effect of clay substitution with waste wood sawdust causes a decrease in the compressive strength of red brick. The compressive strength value of red brick substitution of wood sawdust waste with a ratio of $5 \%$ is $6.25 \mathrm{MPa}$, a ratio of $10 \%$ is $2.64 \mathrm{MPa}$ and a ratio of $15 \%$ is $2.02 \mathrm{MPa}$. Meanwhile, the substitution hydroton caused an increase in the compressive strength of the red brick. At a 5\% ratio of $9.27 \mathrm{MPa}$. However, there was a decrease in the $10 \%$ ratio of $5.06 \mathrm{MPa}$ and the $15 \%$ ratio of $3.4 \mathrm{MPa}$.

b. The density value of red brick without substitution is $1.59 \mathrm{gram} / \mathrm{cm}^{3}$. The effect of substituting clay with wood sawdust waste causes a decrease in the density value of red brick. The density value of red brick substitution for wood sawdust waste has a 5\% ratio of 1.48 grams $/ \mathrm{cm}^{3}$, a $10 \%$ ratio of 1.12 grams $/ \mathrm{cm}^{3}$, and a $15 \%$ ratio of 1.03 grams $/ \mathrm{cm}^{3}$. Meanwhile, the substitution hydroton caused an increase in the density value of red brick at a ratio of $5 \%$ of 1.64 grams $/ \mathrm{cm}^{3}$. However, there was a decrease in the ratio of $10 \%$ of 1.46 grams $/ \mathrm{cm}^{3}$ and $15 \%$ of $1.45 \mathrm{grams} / \mathrm{cm}$.

c. The normal red brick water absorption capacity is $11.14 \%$. The effect of substitution of wood sawdust waste causes an increase in water absorption by $12.04 \%$. This also happened to red bricks with hydroton substitution which also experienced an increase in water absorption by $11.22 \%$. 


\section{References}

[1] A. Pengelolaan et al., "Analisis Pengelolaan Rekam Medis Di Rumah Sakit Umum Pancaran Kasih Manado," Kesmas, vol. 7, no. 4, 2018.

[2] DepKes RI, Pedoman Prosedur Dan Penyelenggaraan Rekam Medis di Rumah Sakit Di Indonesia. DepKes RI Dirjen Bina Pelayanan Medik: Jakarta. 2006.

[3] D. M. Putra, “Tinjauan Pelaksanaan Kerahasiaan Rekam Medis Di Puskesmas Kuranji Padang,” vol. 6, no. 1, pp. 58-66, 2021.

[4] Deni Maisa Putra \& Dila Vadriasmi, "Analisis Penerapan Sistem Informasi Manajemen Rumah Sakit (SIMRS) Di TPPRJ Menggunakan Metode UTAUT DI RS TK.III DR. Reksodiwiryo Padang,” vol. 1, no. 1, pp. 10-18, 2020.

[5] D. M. Putra, D. Z. Yasli, D. Leonard, and Y. Yulia, "Penerapan Sistem Informasi Manajemen Puskesmas (SIM-PUS) PAda Unit Rekam Medis Dan Informasi Kesehatan Di Puskesmas Lubuk Buaya Kota Padang,” no. August 2019, pp. 67-72, 2020.

[6] Menkes RI, "Peraturan Menkes RI No.269/Menkes/III/2008 Tentang Rekam Medis atau Medical Record, Jakarta,” 2008.

[7] T. Wulandari, "Study Literature Review Tentang Implementasi Simrs Pada Unit Kerja Rekam Medis Rawat Jalan Dengan Metode Hot-Hit," Adm. Heal. ..., vol. 1, no. 2, pp. 157-170, 2020, [Online]. Available: http://ojs.stikeslandbouw.ac.id/index.php/ahi/article/view/167.

[8] L. M. Y. Janwarin, N. Makmun, S. Titaley, H. J. Huliselan, and F. The, “Analisis Keterlambatan Pengembalian Berkas Rekam Medis di Rumah Sakit,” Mollucas Heal. J., vol. 1, pp. 30-36, 2019.

[9] M. Husni and D. M. Putra, "Analisis Implementasi Sistem Informasi Manajemen Rumah Sakit (SIMRS) Pada Unit Kerja Rekam Medis Di Rsu'aisyiah Padang,” J. Kesehat. Lentera 'Aisyiyah, vol. 2, no. 1, pp. 19-26, 2019.

[10] Oktamianiza, "Ketepatan Pengodean Diagnosis Utama Penyakit pada Rekam Medis Pasien Rawat Inap JKN (Jaminan Kesehatan Nasional) di RSI Siti Rahmah Padang Tahun 2016," Penelit. dan Kaji. Menara Ilmu, 2016.

[11] Oktamianiza, "Analisis Penerapan Kode Morfologi Pada Diagnosa Neoplasma Rekam MEDIS RAWAT INAP DI RSI Siti Rahmah Padang," vol. 1, no. 1, pp. 55-67, 2020.

[12] D. Makalalag, F. Agushybana, and A. Mawarni, "Evaluasi Sistem Informasi Pelayanan Rekam Medis di RSJ Prof. Dr. V.L. Ratumbuysang Provinsi Sulawesi Utara dengan Pendekatan Hot Fit Model,” J. Manaj. Kesehat. Indones., vol. 5, no. 2, pp. 82-93, 2017, doi: 10.14710/jmki.5.2.2017.82-93.

[13] A. D. Putra, "Evaluasi Sistem Informasi manajemen Rumah Sakit (SIMRS) Dengan Metode Hot Fit Di Rsud Andi Makkasau Kota Parepare," J. Ilm. Mns. dan Kesehat., vol. 1, no. 1, pp. 61-68, 2020, [Online]. Available: http://umpar.ac.id/jurnal/index.php/makes/article/view/294.

[14] O. D. Elvira, D. M. Putra, W. Sumatra, W. Sumatra, and B. R. Medis, "Study Literature Review Tentang Pendistribusian Berkas Rekam Medis Rawat Jalan," vol. 2, no. 1, pp. 161-170, 2021.

[15] S. Erimalata, "Pendekatan Hot-Fit Framework dalam Generalized Structural Component Analysis pada Sistem Informasi Manajemen Barang Milik Daerah: Sebuah Pengujian Efek Resiprokal,” J. Akunt. dan Investasi, vol. 17, no. 2, pp. 141-157, 2016, doi: 10.18196/jai.2016.0051.141-157. 